\title{
HUBUNGAN KENAIKAN BERAT BADAN IBU SELAMA HAMIL TERHADAP BERAT BADAN BAYI SAAT LAHIR DI BPS WIRAHAYU PANJANG BANDAR LAMPUNG
}

\author{
Neneng Siti Lathifah ${ }^{1}$
}

${ }^{1}$ Prodi Kebidanan Fakultas Kedokteran Universitas Malahayati

\begin{abstract}
Relationship Between Maternal Weight Gain During Pregnancy and Infant Birth Weight. Weight gain is needed to support the development of the fetus in your womb. Weight gain for every pregnant woman is not the same. This depends on body mass index (BMI) and body weight before pregnancy. Normal infant birth weight is $2500-4000$ grams, LBW incidence in Indonesia is $6.2 \%$. The purpose of this study is known to have a relationship between maternal weight gain during pregnancy and infant birth weight. This type of research is analytic survey retrospectively with cross-sectional design. Population of 80 pregnant women with a sample of 40 pregnant women who fit the inclusion and exclusion criteria. Univariate research results obtained maternal weight gain according to BMI of $35 \%$ and not according to BMI of $65 \%$, Birth Weight of non-LBW by $52.5 \%$ and for LBW by $47.5 \%$, Maternal characteristics based on parity obtained by multiparous mothers by $75 \%$ and primipara by $25 \%$, based on the characteristics of maternal gestational age there are non-term pregnant women at $57.5 \%$ and a term at $42.5 \%$, the bivariate analysis found there is a relationship of maternal weight gain during pregnancy to birth weight $(p$-value $)=0.002<0.05)$. It is hoped that this research can be a subject of joint study by health workers, especially midwives in providing services during pregnancy, especially in observing the weight gain of pregnant women.
\end{abstract}

Keywords: Maternal Weight gain, birth weight of the baby, Pregnancy

\begin{abstract}
Abstrak: Hubungan Kenaikan Berat Badan Ibu Selama Hamil Terhadap Berat Badan Bayi Saat Lahir Di Bps Wirahayu Panjang Bandar Lampung. Pertambahan berat badan diperlukan untuk menunjang perkembangan janin dalam kandunganmu. Kenaikan berat badan pada tiap ibu hamil tidaklah sama. Hal ini tergantung dari indeks massa tubuh (IMT) dan berat badan sebelum hamil. Berat badan bayi saat lahir normalnya 2500-4000 gram, kejadian BBLR di Indonesia sebanyak $6,2 \%$. Tujuan penelitian ini diketahui adanya hubungan kenaikan berat badan ibu selama kehamilan terhadap berat badan lahir bayi. Jenis penelitian survey analitik secara retrospective dengan desain crossectional. Populasi 80 orang ibu hamil dengan sampel 40 orang ibu hamil yang sesuai kriteria inklusi dan eksklusi. Hasil penelitian Univariat didapatkan kenaikan berat badan ibu sesuai IMT sebesar $35 \%$ dan tidak sesuai IMT sebesar $65 \%$, Berat Badan Lahir yang tidak BBLR sebesar $52,5 \%$ dan yang BBLR sebesar $47,5 \%$, Karakteristik ibu berdasarkan paritas didapatkan ibu multipara sebesar $75 \%$ dan primipara sebesar $25 \%$, berdasarkan karakteristik usia kehamilan ibu terdapat ibu hamil non aterm sebesar $57,5 \%$ dan aterm sebesar $42,5 \%$, pada analisis bivariate didapatkan ada hubungan kenaikan berat badan ibu selama hamil terhadap Berat Bayi Lahir ( $p$ Value $=0,002<0,05)$. Diharapkan penelitian ini dapat menjadi bahan kajian bersama para tenaga kesehatan khususnya bidan dalam memberikan pelayanan selama kehamilan terutama dalam mengobservasi kenaikan berat badan ibu hamil.
\end{abstract}

Kata Kunci : Kenaikan Berat badan ibu, Berat bayi lahir, Kehamilan 


\section{PENDAHULUAN}

Kehamilan merupakan proses alami seorang wanita menjadi wanita seutuhnya yaitu menjadi seorang ibu, dibutuhkan berbagai persiapan yang baik, termasuk persiapan mental menjelang persalinan agar dapat memperlancar proses tersebut. Selama kehamilan terjadi pertumbuhan bayi dalam uterus ibu, semakin lama akan semakain membesar sampai dengan persalinan. Asupan gizi ibu hamil menjadi faktor penting baik untuk pemenuhan nutrisi ibu hamil atau pun untuk pertumbuhan dan perkembangan janin dalam kandungan. Bahkan, dapat mengurangi risiko penyakit kronis pada anak Anda di masa mendatang. Tubuh ibu hamil akan mengalami banyak perubahan fisik dan hormon di masa kehamilan (Gupte, S.2004).

Dalam hal ini, asupan gizi ibu hamil akan memengaruhi kesehatan ibu dan janin dalam kandungan. Ibu Hamil harus memenuhi kebutuhan nutrisi seimbang di masa kehamilan agar bayi terlahir sehat. Nutrisi yang tepat sangat membantu tumbuh kembang buah hati (Siswosuharjo, S., Kes, M., Chakrawati, F., \& Sos, S. 2011). Salah satu perubahan yang dialami ibu hamil adalah berat badan. Pertambahan berat badan ini diperlukan untuk menunjang perkembangan janin dalam kandunganmu (Cunningham, F. G., Leveno, K. J., Bloom, S. L., Hauth, J. C., Gilstrap, L., \& Wenstrom, K. D. 2013). Kenaikan berat badan pada tiap ibu hamil tidaklah sama. Hal ini tergantung dari indeks massa tubuh (IMT) kamu dan berat badan sebelum hamil. IMT didapat dari pembagian berat badan dalam satuan kilogram dengan tinggi tubuh kamu dalam satuan meter kuadrat ( Setyawati, V. A. V., \& Hartini, E. 2018).

Berat badan bayi saat lahir normalnya 2500-4000 gram, kejadian BBLR di Indonesia sebanyak 6,2\% Berdasarkan hasil Riskesdas 2018 (Balitbangkes, R. I. 2018). Bayi yang cukup umur dengan berat lahir rendah biasanya tidak memiliki masalah kesehatan. Namun, lain halnya dengan bayi prematur yang lahir dengan berat badan rendah. Kondisi ini berisiko menimbulkan komplikasi kesehatan yang membahayakan nyawa bayi, seperti gangguan pernapasan, kadar gula darah rendah (hipoglikemia), gangguan makan, rentan terkena infeksi, dan terlalu banyak sel darah merah yang dapat menyebabkan pengentalan darah. Selain gangguan fisik, bayi dengan berat lahir rendah juga berisiko mengalami hambatan pada perkembangan mentalnya. Berdasarkan hasil penelitian yang dilakukan oleh sejumlah ahli, bayi yang lahir dengan berat badan rendah cenderung berpotensi memiliki IQ rendah dan masalah dalam berperilaku di kemudian hari. Masalah psikologis yang mungkin akan muncul berupa kecemasan, hiperaktif serta memiliki fungsi sosial yang rendah (Fadhli, A. 2010).

Bayi besar mungkin memiliki kode genetik berbeda ataupun kondisi medis tertentu selama dalam kandungan yang bisa mempercepat pertumbuhan janin. Tapi para ahli kesehatan mengungkapkan bahwa tren bayi besar lebih terkait erat dengan banyaknya ibu yang mengalami obesitas sebelum dan selama kehamilan. Jika menderita diabetes sebelum hamil (diabetes pra-gestasional) atau Anda menderita diabetes selama kehamilan (gestational diabetes), maka akan lebih mungkin untuk mengandung dan melahirkan bayi besar. Di sisi lain, sebagian besar penyebab dari kasus bayi dengan berat lahir besar tetap tidak dapat dijelaskan, dan kebanyakan bayi makrosomik tidak memiliki faktor risiko yang dapat dikenali. Makrosomia terkait dengan kematian bayi saat lahir, cedera neonatal, kematian ibu, dan komplikasi kelahiran sesar. Di kemudian hari, bayi-bayi ini juga menghadapi peningkatan risiko masalah kesehatan yang menghambat kualitas hidupnya, seperti obesitas, diabetes, dan sindrom metabolik. Selama Kehamilan sangat dibutuhkan pemeriksaan kehamilan 
terutama dalam pemantauan berat badan ibu hamil, sehingga dapat terpantau kebutuhan ibu dan janin selama kehamilan (Yongky, Y., Hardinsyah, H., Gulardi, G., \& Marhamah, M. 2009).

Pada saat Prasurvey pada tanggal 9 Maret 2019 didapatkan kunjungan ibu hamil pada 1 Januari- 1 Maret 2019 ke BPS Wirahayu sebanyak 150 orang dengan kunjungan K1 Perbulan sebanyak 21 orang dan kunjungan K4 30 Orang perbulan. Selama Kunjungan dilakukan pemeriksaan dan penimbangan berat badan ibu hamil, didapatkan dari 10 ibu hamil yang di periksa terdapat 6 ibu hamil yang kenaikan berat badan nya belum sesuai dengan usia kehamilan. Berdasarkan prasurvey dan masalah yang ada maka peneliti tertarik untuk melakukan peneltian dengan judul Efektifitas Kenaikan Berat Badan Ibu Selama Hamil terhadap Berat Badan Bayi saat Lahir d BPS Wiarahayu Panjang Bandar Lampunguan Peneltian. Tujuan dilakukan penelitian ini diharapkan dapat menjadi kajian bersama para tenaga kesehatan khususnya bidan dalam memberikan pelayanan selama kehamilan terutama dalam mengobservasi kenaikan berat badan ibu hamil.

\section{METODE}

Jenis penelitian yang dilakukan yaitu survei analitik. Pendekatan yang digunakan dalam penelitian ini adalah secara retrospektif. Dengan desain crossectional. Variabel dependen Kenaikan Berat Badan Ibu Hamil. Variabel independent Berat Badan Bayi Lahir. Populasi dalam penelitian ini adalah seluruh ibu bersalin dari bulan Januari - April 2019 sebanyak 80 orang Sampel penelitian ini adalah ibu bersalin dari bulan April - Mei 2019 sebanyak 40 orang. Kriteria inklusi : Ibu bersalin yang menimbang berat badan sebelum bersalin. Kriteria Eksklusi : Ibu dengan riwayat Diabetes, Ibu dengan KEK.

Pengumpulan Data yaitu Proses kegiatan penelitian dilakukan setelah proposal diterima, kemudian peneliti mempersiapkan surat permohonan ijin untuk melakukan penelitian di BPM Wirahayu Bandar lampung. Metode pengumpulan data yang dilakukan dengan menggunakan sumber data sekunder yaitu di mana data sekunder dalam hal ini diperoleh dari data rekam medik atau buku KIA ibu hamil, Setelah mendapatkan ijin peneliti melakukan kesepakatan dengan calon responden. Sebelum penelitian dilakukan,peneliti menjelaskan tujuan penelitian. Setelah memahami tujuan penelitian, responden diminta menandatangani surat Pernyataan kesediaan menjadi responden penelitian. Melihat KMS ibu data berat badan ibu sebelum hamil. Menimbang berat badan ibu sebelum melahirkan. Data dikumpulkan dengan kuesioner pada masing - masing responden. Hasil pencatatan yang berupa data interval selanjutnya diolah ke dalam paket Program komputer. Analisa data univariat dilakukan dengan analisis distribusi frekuensi dan hasil Statistik deskriptif. Analisa bivariat dilakukan untuk mengetahui Efektivitas Kenaikan Berat Badan ibu hamil terhadap Berat Bayi lahir. Analisis bivariat dilakukan dengan Chi Square dengan tingkat kemaknaan $95 \%$ (a $0,05)$.

\section{HASIL}

Karakteristik penelitan yang dianalisis yaitu usia kehamilan dan paritas.

\section{Tabel 1. Distribusi Frekuensi Karakteristik Ibu hamil berdasarkan Usia kehamilan di BPS Wirahayu Bandar Lampung}

\begin{tabular}{llll}
$\begin{array}{c}\text { Usia } \\
\text { Kehamilan }\end{array}$ & $\mathrm{N}$ & Frekuensi & $\begin{array}{c}\text { Persenta } \\
\text { se }(\%)\end{array}$ \\
\hline Aterm & & 17 & 42,5 \\
\cline { 1 - 1 } \cline { 3 - 4 } Non Aterm & 40 & 23 & 57,5 \\
\cline { 3 - 4 } & & 40 & 100 \\
\hline
\end{tabular}

Berdasarkan tabel I Karakteristik ibu hamil berdasarkan Usia Kehamilan terdapat 17 orang ibu hamil $(42,5 \%)$ yang usia kehamilan nya Aterm ( $>38-$ 42 minggu) dan terdapat 23 orang 
$(57,5 \%)$ usia kehamilan non aterm. (<38 minggu atau $>42$ minggu).

Tabel 2. Distribusi Frekuensi Karakteristik Ibu hamil berdasarkan Paritas di BPS Wirahayu Bandar Lampung

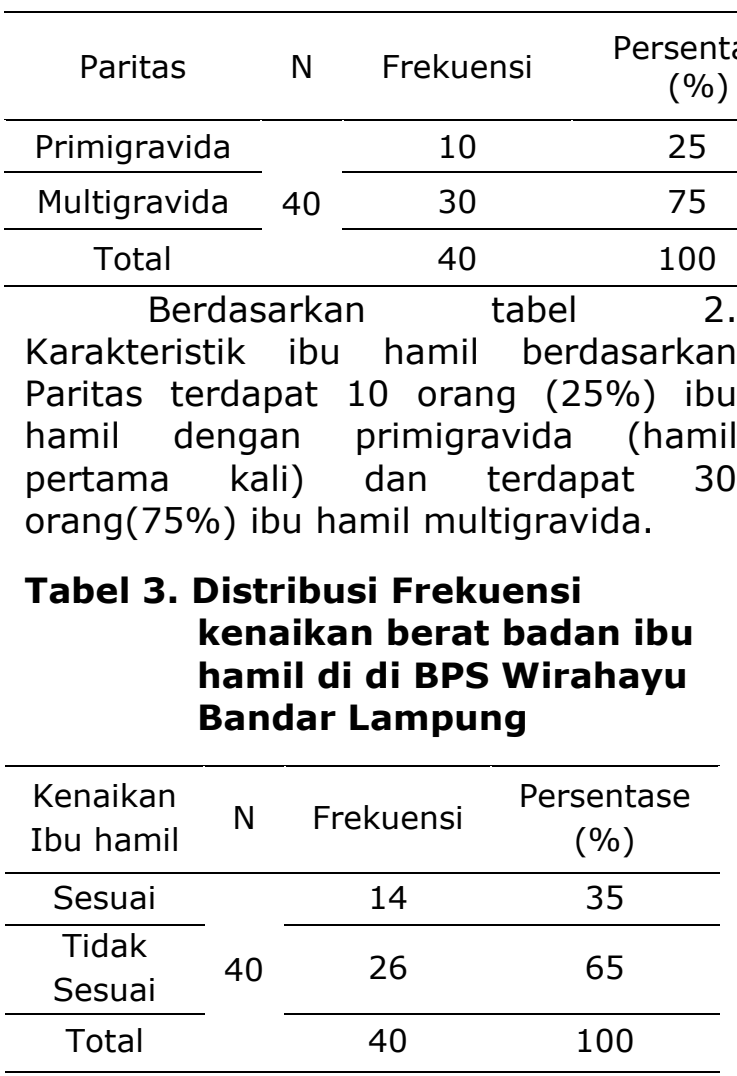

Berdasarkan tabel 3. Kenaikan ibu hamil yang sesuai dengan IMT terdapat 14 orang (35\%) dan yang tidak sesuai terdapat 26 orang $(65 \%)$.

Tabel 4.Ditribusi Frekuensi Berat Bayi Lahir di BPS Wirahayu Bandar Lampung

\begin{tabular}{llcc}
\hline $\begin{array}{c}\text { Berat } \\
\text { Bayi } \\
\text { Lahir }\end{array}$ & $N$ & Frekuensi & $\begin{array}{c}\text { Percentase } \\
(\%)\end{array}$ \\
\hline Normal & & 19 & 47,5 \\
\cline { 3 - 4 } $\begin{array}{c}\text { Tidak } \\
\text { Normal }\end{array}$ & 40 & 21 & 52,5 \\
\cline { 1 - 1 } \cline { 3 - 4 } Total & 40 & 100 \\
\hline
\end{tabular}

Berdasarkan tabel 4.Berat lahir bayi terdapat 19 orang $(47,5 \%)$ yang normal (2500 -4000 Gram ) dan terdapat 21 orang $(52,5 \%)$ yang tidak normal $(<2500$ gram atau $>4000$ gram).

Berdasarkan tabel 5. Terdapat 17 orang ibu hamil yang memiliki kenaikan berat badan tidak sesuai IMT dan melahirkan bayi dengan Berat bayi lahir tidak sesuai dan terdapat 9 orang yang kenaikan berat badannya tidak sesuai IMT tetapi Berat Bayi Lahir sesuai, Terdapat 2 orang ibu hamil yang memiliki kenaikan berat badan tidak sesuai IMT dan melahirkan Bayi dengan Berat bayi lahir tidak sesuai dan terdapat 12 orang ibu hamil yang kenaikan berat badannya sesuai IMT dan berat bayi lahir sesuai IMT dan mempunya P-Value 0,002 $<0,05$ yang artinya terdapat hubungan antara kenaikan berat badan ibu hamil terhadap berat badan bayi lahir.

\section{Tabel 5. Hubungan Kenaikan Berat badan ibu hamil terhadap Berat bayi lahir di BPS Wirahayu Bandar Lampung}

\begin{tabular}{|c|c|c|c|c|c|c|}
\hline \multirow{2}{*}{$\begin{array}{c}\text { Kenaikan } \\
\text { BB ibu } \\
\text { hamil }\end{array}$} & \multicolumn{4}{|c|}{ Berat Bayi Lahir } & \multirow[t]{2}{*}{ Total } & $\begin{array}{c}\text { P- } \\
\text { Value }\end{array}$ \\
\hline & TS & $\%$ & $\mathrm{~S}$ & $\%$ & & \multirow{3}{*}{0,002} \\
\hline $\begin{array}{c}\text { TS } \\
\text { IMT } \\
\end{array}$ & 17 & 65,4 & 9 & 34,6 & 26 & \\
\hline $\begin{array}{c}\text { S } \\
\text { IMT }\end{array}$ & 2 & 14,3 & 12 & 85,7 & 14 & \\
\hline
\end{tabular}

Keterangan :

TS : Tidak sesuai

$S$ : Sesuai

\section{PEMBAHASAN}

Kehamilan yaitu pertumbuhan dan perkembangan dari intrauterin mulai sejak konsepsi sampai permulaan persalinan (Fajrina, A. D. I. B. A. 2012). Status gizi ibu hamil tercermin dari ukuran antropometrinya. Ukuran antropometri ibu hamil yang paling sering digunakan adalah kenaikan berat badan ibu hamil dan ukuran Lingkar Lengan Atas (LLA). Bila status gizi ibu sebelum hamil dalam kondisi baik maka ibu akan melahirkan bayi yang sehat, cukup bulan dan berat badannya normal (Chandrasari, 2017). Menurut Suririnah 
2008, status gizi ibu selama kehamilan sangat berpengaruh terhadap pertumbuhan dan perkembangan bayi dalam rahimnya, apabila status gizi ibu cukup maka pertumbuhan bayi juga akan optimal sesuai dengan masa gestasi. Berdasarkan Teori Nadesul 2008, kehamilan menyebabkan meningkatkatnya metabolisme energi dan zat gizi lainnya. Peningkatan energi dan gizi diperlukan untuk pertumbuhan dan perkembangan janin. Pertambahan besarnya organ kandungan, perubahan komposisi dan metabolisme ibu dan persiapan menyusui ibu setelah melahirkan. Status gizi ibu hamil menentukan berat bayi yang dilahirkan kecukupan gizi ibu hamil bisa dilihat dari kenaikan berat badannya selama hamil. Pertambahan berat badan ibu yang rendah atau tidak sesuai mempunyai resiko tinggi untuk melahirkan dengan bayi BBLR. Sehingga ibu hamil baiknya mengalami kenaikan berat badan.

Hasil Penelitian Terdapat 17 orang ibu hamil yang memiliki kenaikan berat badan tidak sesuai IMT dan melahirkan bayi dengan Berat bayi lahir tidak sesuai dan terdapat 9 orang yang kenaikan berat badannya tidak sesuai IMT tetapi Berat Bayi Lahir sesuai, Terdapat 2 orang ibu hamil yang memiliki kenaikan berat badan tidak sesuai IMT dan melahirkan Bayi dengan Berat bayi lahir tidak sesuai dan terdapat 12 orang ibu hamil yang kenaikan berat badannya sesuai IMT dan berat bayi lahir sesuai IMT dan mempunya $P$-Value $0,002<0,05$ yang artinya terdapat hubungan antara kenaikan berat badan ibu hamil terhadap berat badan bayi lahir. Dari hasil penelitian di atas terdapat ibu hamil yang kenaikan berat badannya tidak sesuai tetapi mempunyai berat bayi lahir sesuai, dan ibu hamil dengan kenaikan berat badan yang sesuai tetapi berat bayi lahirnya tidak sesuai, hal ini dapat disebabkan karena ada faktor lain yaitu usia kehamilan dan paritas.

Semua zat gizi yang diperlukan bagi pertumbuhan janin terdapat dalam makanan yang dikonsumsi ibu. Makanan yang dikonsumsi ibu akan disimpan secara teratur dan terus menerus sebagai glikogen, protein, dan kelebihannya sebagi lemak. Hal tersebut berguna untuk memenuhi kebutuhan energi, kebutuhan ibu untuk kehamilannya, dan pertumbuhan janin (Cunningham, 2013). Dibandingkan ibu yang tidak hamil, kebutuhan ibu hamil akan protein meningkat hingga $68 \%$, asam folat $100 \%$, kalsium $50 \%$, dan zat besi 200-300\%. Bahan makanan yang dikonsumsi oleh ibu hamil harus meliputi enam kelompok makanan yaitu makanan yang mengandung protein hewani maupun nabati, susu dan olahannya, roti dan bebijian, buah dan sayur yang kaya akan vitamin C, sayuran hijau, serta kelompok buah dan sayur lainnya (Arisman, 2009). Kekurangan nutrisi pada wanita pada masa reproduksi dapat mempengaruhi kesehatan ibu baik sebelum hamil, selama kehamilan, dan setelah masa kehamilan. Pada masa sebelum kehamilan dapat mengakibatkan rendahnya berat badan dan berkurangnya cadangan lemak. Pada masa kehamilan dapat mengakibatkan berkurangnya durasi kehamilan dan rendahnya pertambahan berat badan selama hamil. Serta pada masa setelah kehamilan dapat mengakibatkan berkurangnya produksi Air Susu Ibu (ASI) (Manuaba,2009). Penyimpanan lemak ibu selama kehamilan akan mencapai puncaknya pada trisemester kedua dan akan menurun seiring dengan meningkatnya kebutuhan janin pada akhir kehamilan. Hal ini tentu akan berpengaruh terhadap berat badan ibu selama kehamilan (Cunningham, 2013). Asupan makanan ibu yang terganggu akan mempengaruhi penyimpanan dan kebutuhan energi bagi ibu dan janin yang sedang dalam pertumbuhan. Selain peningkatan deposit, penambahan berat badan ibu selama kehamilan juga disebabkan oleh pertumbuhan uterus dan isinya (Shidiq,2015).

Pertambahan berat badan ibu hamil tidak hanya dipengaruhi oleh perubahan fisiologis ibu, tetapi juga dipengaruhi oleh karakteristik lain dan faktor biologis (metabolisme plasenta). Fungsi plasenta adalah sebagai organ 
endokrin dan zat perantara ibu dan janin. Perubahan homeostatis dapat merubah struktur dan fungsi plasenta yang berdampak terhadap kondisi pertumbuhan janin. Plasenta dapat mempengaruhi sistem metabolisme ibu karena adanya perubahan hormon insulin dan sistem peradangan, sehingga berakibat pada pertambahan berat badan ibu hamil (Wijaya, A. K. (2017). Ada masyarakat mampu, hubungan konsumsi kalori dan berat lahir bayi tidak tampak nyata. Terlebih ibu yang gemuk, walaupun konsumsi kalori dikurangi, berat bayi lahir tetap normal. Pada keluarga ekonomi rendah, asupan kalori berpengaruh besar pada kenaikan berat badan dan berat lahir. Hal tersebut tergambar dalam penelitian ini, dari data univariat diketahui bahwa sebagian besar (88.5\%) dengan proporsi pengeluaran untuk pangan $>$ $62.8 \%$, yang menurut BPS/UNDP termasuk dalam kategori miskin. Demikian pula bila dilihat dari status gizi pra hamil masih terdapat ibu menderita KEK, ibu dengan berat badan $<42 \mathrm{~kg}$ $(16,7 \%)$ atau ibu dengan IMT $<18.5$ $(9.6 \%)$.

\section{KESIMPULAN}

Terdapat hubungan antara kenaikan berat badan ibu hamil terhadap berat badan bayi lahir dengan $P$-Value $0,002<0,05$. Jika kenaikan berat badan ibu saat hamil sesuai dengan IMT Maka berat bayi yang dilahirkan akan sesuai. Saran bagi penelitian kedepannya menjadi bahan kajian para tenaga kesehatan khususnya bidan untuk lebih focus dalam konseling nutrisi pada saat pemeriksaan ANC dan memantau tafsiran berat janin.

\section{DAFTAR PUSTAKA}

Arisman, M. B. (2009). Buku ajar ilmu gizi: Gizi dalam daur kehidupan. Jakarta: Penerbit Buku Kedokteran EGC, 2, 275.

Balitbangkes, R. I. (2018). Hasil Utama Riskesdas 2018.

Candrasari, A., Romadhon, Y. A., Auliafadina, F. D., Firizqina, A.
B., \& Marindratama, H. (2017). Hubungan Antara Pertambahan Berat Badan Ibu Hamil dengan Berat Badan Lahir Bayi di Kabupaten Semarang. Jurnal Penelitian Sains Teknologi, 13(1), 56-62.

Cunningham, F. G., Leveno, K. J., Bloom, S. L., Hauth, J. C., Gilstrap, L., \& Wenstrom, K. D. (2013). Obstetri Williams (Williams Obstetri). Jakarta: EGC

Fadhli, A. (2010). Buku pintar kesehatan anak. Pustaka Anggrek.

Fajrina, A. D. I. B. A. (2012). Hubungan Pertambahan Berat Badan Selama Hamil Dan Fakor Lain Dengan Berat Badan Lahir Di Rumah Bersalin Lestari Ciampea Bogor Tahun 2010-2011. FKM UI.

Gupte, S. (2004). Panduan perawatan anak. Yayasan Obor Indonesia.)

Manuaba, I. A. C. (2009). Memahami Kesehatan reproduksi wanita ed 2. EGC.

Nadesul, H. (2008). Cara Sehat Menjadi Perempuan. Penerbit Buku Kompas.

Setyawati, V. A. V., \& Hartini, E. (2018). Buku Ajar Dasar IImu Gizi Kesehatan Masyarakat. Deepublish

Shiddiq, A., Lipoeto, N. I., \& Yusrawati, Y. (2015). Hubungan Pertambahan Berat Badan Ibu Hamil terhadap Berat Bayi Lahir di Kota Pariaman. Jurnal Kesehatan Andalas, 4(2).

Siswosuharjo, S., Kes, M., Chakrawati, F., \& Sos, S. (2011). Panduan super lengkap hamil sehat. PT Niaga Swadaya.

Yongky, Y., Hardinsyah, H., Gulardi, G., \& Marhamah, M. (2009). Status gizi awal kehamilan dan pertambahan berat badan ibu hamil kaitannya dengan BBLR. Jurnal Gizi dan Pangan, 4(1), 812.

Wijaya, A. K. (2017). Hubungan Pertambahan Berat Badan Ibu Selama Kehamilan Dengan Berat Bayi Lahir Pada Primipara Dan Multipara. 